\title{
SOCIOLOGY OF SOCIAL STRUCTURE AND SOCIOLOGISTS WORKING IN TOTALITARIAN AND POST-TOTALITARIAN REGIMES IN CENTRAL EUROPE, 1945-1989¹
}

Georges Mink

Institut des Sciences Sociales du Politique, Centre National de la Recherche Scientifique (ISP_CNRS France), Paris College of Europe, Natolin, Warsaw

We are apt to forget that the production of sociological knowledge in Sovietised countries was not a linear process of accumulating survey data and analysis and that while most sociologists had chosen the profession as a vocation, they might suddenly find themselves ejected from a quiet academic career into total professional inactivity. The institutionalisation of sociology in Central Europe was a complicated process and the discipline did not fully acquire its independence until 1989, though many sociologists did find a way to express themselves freely before then, particularly when communism began to decline, either by remaining anonymous or taking up a position on the opposition side. Toward the end of the communist regime, sociology was neither entirely submissive or fully autonomous; it continued "obedient" in what was a sort of "chiaroscuro" academic environment, as attested by the extremely high frequency of publishing in "internal" or "grey" publications - what Eastern Europeans called the "second circuit," less dangerous than samizdat: neither public or private, small print runs, texts accessible to no more than a few hundred privileged readers. Nonetheless, the progress that began to be made as early as the 1950s was impressive. Initially, the steamroller of Soviet ideology flattened

\footnotetext{
${ }^{1}$ This text is part of a book in preparation on sociology, sociological production, and the producers of sociology, that is, sociologists working under the Soviet system in Poland, Czechoslovakia, Hungary, and incidentally, Soviet Russia.
} 
sociology down to a "bourgeois science" practised by the "lackeys" and "salaried slaves" of capitalism, while declaring that its only purpose was to "counter-attack true Marxist-Leninist social science." The violence with which sociologists were excluded was equalled only by the Soviet and Sovietised states' megalomaniac ambition to dominate and control the social sciences. "In the early 1950s [in Sovietised Europe], the Marxists wanted to replace sociology with historical Marxism. [...] State power, state money, the state police and state censorship were behind the "historical materialists,' helping them combat ordinary sociologists" (Karpiński 1985: 250). ${ }^{2}$ But as Raymond Aron pointed out quite early on: "In fact, Central European professors converted to sociology the day they stopped merely citing the laws of historical evolution as formulated by Marx and began questioning Soviet reality itself by way of statistics, questionnaires and interviews" (Aron 1963: 14). Russian sociologists recall this moment with a note of pathos: "1950 marked an extremely important event for Soviet sociology: historical materialism moved outside the universities and entered 'real life.' This event was comparable to a scientific revolution [sic!]. A similar revolution had taken place in the late nineteenth and early twentieth century when the Chicago sociologists "went out into the streets"' (Batygin \& Deviatko 1995: 29).

This description may seem something of a caricature. And yet despite the gradual policy shift from outright expulsion of sociology from the sciences to institutionalisation of the discipline, sociology did not entirely cease its "obedient" ways until communism collapsed. The lightning-speed development of what became in the 1970s and 1980s a fashionable discipline did not mean that retrograde institutions had disappeared (compare the sociology institutes close to party central committees and created for exclusive government use) or that there was no danger of regression. The Czech sociologists who drove the cognitive development of the discipline in the late 1960s, for example - and who of course had no intention of serving the "normalisers" of the Prague Spring - paid for their sins either by emigrating or doing all sorts of odd jobs to survive. Many Hungarian and Russian sociologists chose expatriation to the West and the fall in professional status thereby incurred, over censorship constraints.

Very quickly, however, the various contradictions between knowledge and power, obedience and professional ethics, began to open up new opportunities.

\footnotetext{
${ }^{2}$ All translations of cited fragments are my own.
} 
The situation for sociology and sociologists in a Soviet-type political system might be summarised thus: sociologists were competing with ideologists anxious to preserve their monopoly grip on the labour of presenting and interpreting "social facts"; the effect of sociologists' labour of observation was to contradict the dogmas of the dominant ideology. Toward the end of the 1980s, the boldest representatives of the discipline, Elemér Hankiss included, had the feeling they were constantly moving on the "razor's edge" (see Mink 1987a).

Given the partial emancipation of alternative sociology, communist governments were faced with the choice of either eradicating sociology from universities and academies or "domesticating" it. Those with liberal, reformist inclinations (Kadar) or technocratic (Gierek) or modernising ones (Jaruzelski, Gorbachev) chose the latter solution. This in turn generated a new space between state power and the "human" sciences, a space in which newly reactivated national professional traditions had to be taken into account, together with all the sudden new international contacts and the connections that were developing between sociologists and what were as-yet embryonic civil societies. The powers-that-be accepted this situation because they thought they could derive all sorts of benefits from it. Batygin and Deviatko cite the following anecdote: "In late 1955, the Soviet delegation was preparing its contribution to the Third World Congress of Sociology in Amsterdam. The delegation's tasks were formulated thus: to study our ideological enemies, and to establish contacts with bourgeois sociologists who have progressive sociological opinions. [...] For decades most of those sent to participate in world congresses were ideological functionaries" (Batygin \& Deviatko 1995: 31).

National sociology itineraries were caught between two boundaries: on one side, the state; on the other, the sum of individual sociologists' strategies. A fundamental given of all such strategies (at least those developed within an institutional network) was the sociologist's position vis-à-vis the state, since the state had a monopoly on recruitment, jobs, and funding. An entire panoply of attitudes developed in the space that had been opened up, ranging from sociologists extremely close to the powers-that-be (some even belonged to the power elite) to sociologists at odds with the state. Several salient professional profiles can be distinguished.

My work relies on an extensive interview survey of sociologists in the 1980 s. $^{3}$ The interviews were conducted in quite diverse places - above all,

${ }^{3}$ The surveyed sociologists belonged to various generations (nota bene: a number of them requested to remain anonymous). Poland: Władysław Adamski, Jakub Karpiński, Grażyna Gęsicka, Janusz 
in my home in Paris, but also in Budapest, Warsaw, Prague, and Moscow. One interview even took place in New Delhi on the occasion of an international sociologists' conference in 1985. Previously, the survey has only been used in part, for minor publications. Today, it provides an invaluable self-portrait of sociological milieus under the late Soviet system. The interviews occurred during the period from 1984 to 1990. They were of the semi-structured variety and used a set of repeatable questions. A large number concerned the interviewee's personal and professional trajectory (the comparative aspect of our analysis); other questions were ethos-related and could involve casual, voluntary exchanges of political opinions with the interviewer. In conducting the survey I collaborated with Dr Pawel Kuczyński in Poland and Dr Zuzanna Elekes in Hungary. I surveyed sociologists from Czech and Russian territories myself.

I also based my empirical analysis on a study of sociologists' works, particularly those concerning social structures and describing the social system and/or socio-political system. Given the premises of my research, I omitted branches of sociology other than the sociology of social systems (structure). My central hypothesis was that the evolution of professional behaviours and theoretical approaches is caused by active competition between the political power's dogmatic monopoly over social diagnoses and the growing vitality of the corps of sociologists. Such an approach derives from an interpretation of Kuhn's theory of scientific revolution, but it also takes into account the neo-institutional paradigm (the influence of institutional-systemic frames and leading ideas about behaviour - ethoses). Neoinstitutionalism declares that there is a correlation between professional attitude, the struggle against regulation, and paradigmatic competition with the obligatory dogmas legitimating an authoritarian power of the Soviet type. This hypothesis takes into account the variability of systemic conditions, while the analysis also includes a historical approach. In other words, the 1950s, when the Soviet system was nearly hermetic, were not like the 1970s and 1980s, which were years of increasing crisis. The power elites themselves, by making dogma flexible for the sake of socio-technical diagnoses, opened new areas for sociologists' activities. In my analysis I have

Gęsicki, Andrzej Tyszka, Andrzej Rychard, Włodzimierz Pańków, Adam Sosnowski, Małgorzata Melchior, Maria Halamska, Krzysztof Szafnicki, Ireneusz Krzemiński, Marek Tabin, Maria Łos, Włodzimierz Wesołowski, Jerzy Wiatr, Piotr Kryczka. Hungary: Zsusza Elekes, Zsusza Ferge, Rudolf Andorka, Elemér Hankiss, Laszlo Bruszt, Tamás Pál, Michal Suskod, Tamás Kolosi, Susanne Horvath, Robert Manchin, György Lengyel, Czako Mihaly, Solt Ottilia, Gábor Havas, István Kemeny. Czechoslovakia: Zdeněk Strmiska, Pavel Machonin, Milan Petrusek. USSR: Guennady Batygin. 
also used the interactionist paradigm, on the assumption that the group of sociologists operates in a field (in Pierre Bourdieu's sense). That field thus becomes an interactive network, which shapes and influences the evolution of academic attitudes and is divided along two axes: the political power and the opposition; and the professional ethos and society.

Consequently, the article is structured around two themes: on the one hand, it typologises the sociologists' positions on the power/opposition axis; and on the other, it shows the evolution of theory in the academic sphere under the varied impulses to which sociologists are subject, that is, the desire to be a neutral expert or to serve society. The field is affected from outside by a dual contextual logic: by political control ensuing from the legitimating coercion of Soviet-type authorities, and from the need, which rises with the crisis, for those same authorities to understand social reality in order to make the necessary political adaptations.

\section{/// Sociologists on the Side of the Communist Power}

At least three such profiles crystallised into a movement that gravitated around the Communist Party in power. Those closest to the Party could be called "teleological counsellors to the Prince," that is, Party members aspiring to join the highest spheres of authority as "organic intellectuals." For them, science was clearly a means of attaining an ideological objective: the purpose of sociology was to help the Regime manage its transitory difficulties - including as a tool for manipulating public opinion. When it became clear that Sovietised societies were inherently - that is, as a result of their own logic - inegalitarian, these Party sociologists sought above all to remedy the legitimacy problem, or void, created by that fact. They invented justifications based on "dynamic" conceptions of egalitarianism or a "meritocracy," thereby rendering ideologically conceivable, and therefore legal, the fact that some social groups were acquiring wealth at the expense of others - for example, the workers, who were, of course, theoretically, the social base of the regime. Ingenious at thinking their way through and around Marxist doctrine, these sociologists fabricated the category of "deserving workers" (i.e., foremen), a kind of worker-aristocracy that, by its merits, came nearer to "real socialism" than the rest of the working class. Here they had patently borrowed the "affluent workers" concept from Western sociology. And it was a sociologist in military uniform, Colonel Stanisław Kwiatkowski, who was appointed by General Jaruzelski to head the new Polish Polling Institute: not so the Institute could lie to the popu- 
lation about the nature of the 1981 coup - the communists had already learned that lying was entirely counterproductive - but to generate and diffuse half-truths that might destabilise social resistance.

There were two other categories of sociologist who deliberately sailed along in the wake of the powers-that-be: "technocratic counsellors to the Prince" and "entryist counsellors." The first type were convinced themselves, and desirous of convincing any listeners, that the social sciences were neutral; they positioned themselves equidistant from the state and civil society and their aim was to find an enlightened interlocutor within the state elite through whom state policy might be inflected. When after many attempts it became clear this would not work, they lost faith and became cynical.

"Entryist" counsellors drew on the two preceding styles. They thought of themselves as "ambassadors" of society while claiming to have inside knowledge of the powers-that-be and their vulnerabilities thanks to their connections with the state. Their credo was that sociology should work to attenuate conflictual situations caused by the failure of communication between communist governments and their fairly anti-communist populations. Manipulated by their informers, these sociologists suffered from split identities and the rapidly weakening credibility of the role they had assigned themselves - especially since the only way to convince the governments of their good faith was to censor themselves.

\section{/// Itineraries Ranging from an Emphasis on the Professional Ethos to Full Commitment to the Cause of Society}

Everything in this matter was a question of emphasis. A sociologist's uppermost concern might be his or her professional career, the scientific ideal - in which case a degree of self-abnegation was required - or serving the population and perhaps the political opposition. In the first group, there were "independent scholars" on one side and "careerists" on the other. For the former, remaining neutral with regard to the state was a matter of principle. They therefore kept their distance from social movements and conflicts between governors and the governed. Academically, they took refuge in highly specialised areas with particular vocabularies, far from both ideology and current empirical events, and showed a predilection for methodological inquiry or the history of social thought. Intensely concerned about their professional status, they were sensitive to competition within 
the professional hierarchy and therefore censored their own hypotheses and findings. In fact, they were not too different from their "careerist" counterparts, whose ambition to attain professional success took them as far as joining the Party without sharing its convictions, because, as they saw it, "passive" membership was the only way forward in the profession.

\section{/// Sociologists on the Side of Society}

Then there were the different types of sociologists under the ancien régime who sought to serve society. For "independent experts," the goal was wide diffusion of their empirical findings. They often specialised in the sociology of factory management, a field that the communist authorities allowed to develop as a way of obtaining supervision for good workers and information on factory workers' attitudes. Independent experts refused to let their research be instrumentalised by state actors. Sensitive to what they understood as the erosion or corruption of what the regime proclaimed were socialist society's dominant values (equality, justice, etc.), they tended to investigate pathological phenomena of social and labour life, laying responsibility for them on the authorities. Faced with preventive censorship, they sought to have their research published abroad or through independent channels.

"Independent experts" often overstepped the boundary and became outright opponents of the state as "experts of the social movement," though this type of sociologist was only really found in countries where social movements had in fact developed, namely, Poland and Hungary. In Poland, independent experts sporadically served the Solidarity trade union movement; in Hungary, they worked with the poor, the Roma, conscientious objectors, environmentalists, and retirees. They valued research on values, and were not averse to expressing conviction-based judgments - at the core of which was the notion of truth - in their analyses.

At the far end of the spectrum were "activist sociologists," whose actions reflected an absolute refusal to compromise with the authorities, though this put them in very real danger of losing institutional and material status. Activists ended up joining the political opposition. Some dispensed with methodology in the interest of quick diagnoses that went against "official" sociology, about whose findings they were sceptical; they claimed official findings were based on biased observations as respondents had surely not answered sincerely. 


\section{/// The Effects of Communist-Regime Sociology "Obedience"}

The effect of these sociologists' research was to destroy the idyllic image of a harmonious society, but this hardly liberated the sociologists themselves from a paradoxical dependence on the communist government. As communist-regime sociology had no control over its products, it was extensively used as an instrument - at first, against the will of the "producers." For example, sociologists' claim of a strong correlation between extensive growth (the Soviet model, the understanding that economic growth requires the qualitative mobilisation of all resources) and overall upward social mobility actually supported, if indirectly, the idea that socialist planning was "progressive," "rational," or even "infallible." So not only did sociologists who made that claim accredit the founding dogma of Sovietisation, but due to their own professional credentials they instilled in the minds of system actors an explicit representation of Sovietisation as legitimate. Once the issue of inequality had been accepted as a legitimate research subject for sociology (in the 1960s in Poland and Hungary), the governments themselves could declare a need to modernise social dogma, and could therefore legitimate a kind of meritocracy - precisely the one on which government stability depended. Sociology itself, then, had given the governing powers the argument they needed.

In fact, "obedient" sociology was driven by the paradox of using a science whose inherent tendency was the denunciation of the illegitimacy of the powers-that-be to legitimate those very powers. What could be more logical than a sociologist forced to work in conditions where the partystate's social doctrine had absolute priority over any and all type of independent social thought - and party-states were of course quick to intervene and "rectify" any thesis that could be considered deviant - what could be more logical than that such a sociologist would seek to make independent judgments in the interest of society? And yet that logic also came into conflict with the sociologist's desire for independence. In fact, sociologists actually avoided criticising the dominant doctrine because they had confused the interests of society with the possibility of "freely" practising their own profession. In the end, the tree - that is, one's own "freedom" - concealed the forest. An example here would be the highly sophisticated (for the time) studies of social stratification done in the 1970s in Poland. Being allowed to use Western methodological tools did indeed amount to a political victory, but the studies themselves reached the conclusion - just before the Solidarity workers' union emerged on the scene in 1980 - that Polish 
society was in the process of reducing the tensions caused by unequal social status, or at least that acting on a single-status dimension could effectively reduce feelings of injustice.

Another example concerns what has been called the Soviet power's "opinion poll-itis" (sondażomania in Polish). According to this argument, the Soviet power was already "senile" and incapable of grasping what the governed thought of their governors. It resisted opinion polls at first because they discovered heterogeneity within the population and contradicted such dogmas as the friendly alliance between workers and peasants, the primacy of internationalism over patriotism, and the thesis that attitudes and values were unanimous. But the powers-that-be let sociologists convince them that opinion polls were a neutral technique that might replace democratic consultation. During the 1970s and 1980s, opinion polls proliferated. They were conducted under the egis of opinion centres founded by and linked to those same powers-that-be, which also provided an amount of financial and material resources that would have made such honourable Western institutions as Gallup Polls green with envy. The government's paradoxical aim at the time was to demonstrate to the population the diversity of opinion existing within it so as to short-circuit any general understanding that society was in fact unanimously against the governing power (see Mink 1975, 1981, 1988).

Sociology thus manifested its obedience in many ways, some of which were quite circular. To legitimate their discipline in the eyes of power, some sociologists were willing to use all their scientific prestige to legitimate that power. In some cases, this meant sociologists "knowing" or "being apprised" of what topics had become taboo so they could deliberately avoid discussing them.

\section{/// Imposed Figures and Views of "Communist" Society after the Fall of Communism}

There was no break-up or implosion of the "corporation" of sociologists after the fall; sociologists were not persecuted for collaborating with the ancien régime or socially declassed and there was barely any change in position distribution. Critical but "entryist" sociologists did forfeit their top positions to apolitical or dissident sociologists, and this change corresponded to a slight generational shift as sociologists in their forties and fifties, who had been prevented by Party sociologists from attaining the highest pro- 
fessional positions (e.g., head of a prestigious or well-funded opinion institute), were propelled into positions of responsibility.

Moreover, since the research tools were already present, previously acquired knowledge could be recycled for the entry into the post-communist era.

In fact, the handicap that put the newly post-communist sociologists at a disadvantage had to do with the vicissitudes of sociology as a discipline, how it was practised, the approaches, paradigms, hypotheses, and objects of observation that it "chose" at the time or that came to the fore - as if the freedom of movement of sociologists everywhere had somehow been "mortgaged."

\section{/// Domination of the Sociology of Structure over the Sociology of Change or Action and Its Effects}

At just the time the ideological borders of the Sovietised world opened up a chink, sociology worldwide came to be heavily dominated by the already traditional distinctions between social dynamism and stasis (Comte) and between structure and function (Spencer). For Piotr Sztompka, these conceptual dichotomies amounted to an original sin that moved the sociological "corporation" to construct two artificially separate sets of theories, one to explain wholes and continuities, the other to understand and explain change and breaks in continuity. The dominant conviction was that the only objects that sociologists could observe and the only types of social logic at work were those pertaining to a "social order," to structural regularity and a tendency to balance "systems," or to social wholes or enduring "social institutions." In this general understanding, change was disqualified as a "disruptive factor and foreign object" and excluded from sociological analysis. Zygmunt Bauman recently explained how the cognitive horizon was determined, not to say closed, in the 1950s, 1960s, and, though less firmly, the 1970s as well. He refers to the episode in American sociology where Alex Inkeles asked Wilbert Moore to describe "social change." At that time (1963), sociological theory dictated that sociologists were to see all change as an "abnormal" state. Moore answered by proposing to develop a full-fledged theory alongside of the structural paradigm - as if the two phenomena were independent of each other. The absence or weakness of a sociology of action fit very nicely with the communist taboo against collective social movements made up of workers or led by intellectuals. 
Let me briefly review the long, difficult struggle of Eastern European sociologists to win acceptance and even dominance for explanatory paradigms that refused to grant any heuristic value to the Soviet dogma of a "harmonious society" composed of workers, peasants, and the intelligentsia. This propagandistic triad, with its representation of the social structure as a whole free of any major antagonism, had the force of law. It was inscribed in Soviet-world constitutions. And according to the Marxist scheme, it was scheduled to disappear: differences between the three components would be eroded or levelled, thereby "homogenising" them.

The first sociologists to criticise this schema were the Marxists, who had been granted permission to practise their profession by the communist powers-that-be - though they were, of course, under close surveillance. Paradoxically, it was when they found themselves faced with the dilemma of loyalty to the dogma or to a professional ethos that several of them chose to practise partially "disobedient" sociology. The work and history of the Marxist current amounts to little more than attempts to render official dogma operational. In the 1960s, Marxist sociologists in Poland, Hungary, and Czechoslovakia made two observations that led them to start systematically inventorying sources of conflict and centrifugal forces in the new social structure:

a) Unlike capitalism, socialism did not engender structural conflict between two essential classes, that is, owners of the means of production and owners of labour power (only). The fact that capitalists and large landowners had been stripped of their property meant that the binary opposition between workers and capitalists no longer held. The mechanism that used to generate inequality that is, private ownership of the means of production - had ceased to operate, and the dichotomous class division based on one class's constant appropriation of the added value created by another had been abolished.

b) But empirical observation had demonstrated that despite the fact that the fundamental antagonism between workers and capitalists could no longer function as the basis for a description of how individuals were positioned in the social structure, the particular condition of workers had not disappeared. In fact, most of the dimensions characteristic of class situation remained in place. So, little by little, through a gradual shift from concepts to indices, Marxist sociologists slipped the grip of the idyllic official representation and began working to impose the conflict-of-secondary-interests 
paradigm. Those conflicts were situated in the distribution sphere. The relevant theory here was Julian Hochfeld's "maximising advantage and minimising suffering" (Hochfeld 1963). The sociology school of Budapest, protected by Andreas Hegedus, took up where Hochfeld's thinking left off (see Mink 1987b). These sociologists managed to start with the dominant doctrine and open up a space of observation. The sociologist Zsuzsa Ferge, who was close to Hegedus, considered that members of society assess existing inequalities with reference to the theory that social equality can exist. This explains why, following her rationale, relatively minor inequalities can cause tensions (Becskehazi \& Kuczi 1995). In this way the idea was introduced that there could be competition between different social groups around what were in fact temporary conflicts of interest that did not fundamentally call the system itself into question.

But Marxists sociologists ran up against what appeared to be a theoretical obstacle yet was in fact a political one. If the only inequalities in socialist society were those inherited from the pre-communist past, which were therefore doomed to wither away, then what was driving development of the new inequalities? It was this question that proved fatal to the regime. When Zygmunt Bauman (1964) or Włodzimierz Wesołowski (1962) raised the question of political power and the determinant role of an individual's position in the political hierarchy - the implication being that the political elites were in a good position to appropriate the famous value added (Jacek Kuron and Karol Modzelewski's theory is the culmination of this line of thought (1967)), it was clear that the cognitive resources of what was known at the time as the revisionist Marxist approach had been exhausted. That door was now closed, and sociologists wishing to reopen it would have to become open opponents of the powers-that-be.

Then began the era of "Marxist-Weberian" sociology, ushered in with a wave of research on multidimensional stratification conducted in Hungary by Zsuzsa Ferge, Istvan Kemeny, Rudolph Andorka (Hungarian Statistical Office 1967) and others; in Poland by Włodzimierz Wesołowski and Maciej Słomczyński (1977); and in Czechoslovakia by Pavel Machonin and his team and their renowned survey.

That the social structure remained the exclusive ideological domain of the political power is attested by what happened to these Czechoslovakian sociologists. The price Pavel Machonin paid for investigating Czechoslovakian socialist society was twenty years of conducting entirely unrelated 
studies in a farming cooperative; his colleague Zdenek Strmiska chose exile in Paris. After the Prague Spring of 1968, it became dangerous to distance oneself at all from the social dogma of the harmonious society. It was Machonin's team who put forward, in Ceskoslvenska Spolecnost [Czechoslovak Society], the hypothesis that the communist powers-that-be enjoyed privileges in all dimensions of social life.

While analyses of social stratification improved knowledge of Soviettype societies, particularly by quantifying inequalities and differentiations, they did not provide insight into change mechanisms since the stratification paradigm can only explain functions, or at best how dysfunctions are absorbed; it cannot probe how social actors came into being, or social movements rooted in unequal distribution of civil and political rights.

Enriching the stratification paradigm with interactionism and behaviour theories, as Andrzej Malewski did in his studies of Poland (1964), should have encouraged sociologists to look for discontinuities in the social structure in terms of status incongruence and dissonance, in line with the hypotheses of Gerhard Lenski or Léo Festinger. Paradoxically, however, whereas the enriched stratification paradigm took over for nearly a decade (the 1970s) due to the work of Wesolowski and his team, it generated a counterhypothesis, that is, the "theory of the decomposition of class characteristics," whose corporatist aim was to demonstrate the professionalism of sociological study by demonstrating its ability to objectively identify all dimensions of social diversity using reliable tools. This ultimately led to formulating the explanation that differences found in the level of individuals' social positions ("high," "low") did not engender discontent or frustration because there were other compensations. For example, a doctor who was paid less than an unskilled worker did not manifest "categorical" discontent because his prestigious position on the social ladder compensated for any potential feeling of deprivation. Conversely, discontent was not generated among workers with manual skills that had been relegated to the bottom of the prestige scale, because such skills gave them greater material satisfactions than those found in occupations of higher repute. Clearly, sociologists had made a paradoxical finding that was of great comfort to the political powers-that-be: their decision to underline the superiority of their professional techniques - that is, their objectivity, which derived from their being at least partially professionally independent of communist ideology - had generated data that was reassuring on the question of the stability of a social system which was, in fact, already being undermined by the first public movements of contestation. 
In Poland the increasing number of signals that the political and social system was unstable, particularly at the end of the 1970s, gave rise to a "populist" school of sociology that described Soviet-type society as increasingly inegalitarian. It used extremely strong, irreducible binary oppositions, now openly setting the political powers-that-be - them - against the population (or the working class or civil society): us (Malanowski 1981; Tymowski 1977). Timorously, sociologists began to focus their research on the communist nomenklatura, beginning with the middle echelon (Wasilewski 1978), in order to identify beyond any doubt the determinant differentiator role played by the political factor and to publicise that finding.

In the 1980s, the question became why, when normalisers in Czechoslovakia had effectively "starved" sociology, sociologists in Poland and Hungary developed such divergent approaches to their respective societies (though they did share a remarkable ability to demystify communist dogma). Sociologists in both societies described the symptoms of a new dual class structure, whereas it was primarily in Hungary that some sociologists set out to describe their mechanisms and therefore their causes. Sociologists investigating symptoms set about, for example, calculating income gaps, which had attained a range of 1 to 20 (not to mention the income of members of political rank), or defining the poverty line and describing manifestations of it, thereby daring to invalidate the last taboo of socialist propaganda - the claim that communism had definitively eradicated the phenomenon of poverty so particular to capitalist regimes. Sociologists investigating mechanisms blamed the new social divisions on the individuals who dominated distribution and redistribution mechanisms. György Konrád and Iván Szelényi (1979) found a growing correlation between belonging to the Communist Party and possessing management skills attested by increasingly high educational degrees (see also Szelényi 1986-1987). While belonging to the nomenklatura had always been essential for anyone wishing to gain access to the ruling class, in the late 1980s education and political adhesion were gradually becoming necessary for access to distribution and redistribution mechanisms. In support of this thesis, studies of social mobility began to show that the political and educational elites (the intelligentsia) increasingly overlapped and "reproduced." This in turn led to the thesis that the intellectuals were "on the road to class power" in socialist countries (a way to avoid saying they had taken over).

The priority in both approaches was to examine and explain the stability of the Soviet system, and this included reflecting on possible adaptations of deviant mechanisms (Iván Szelényi, Elemér Hankiss, Rudolph 
Andorka). The exhaustion of the "structuralist" paradigm led some Polish sociologists to try a systemic approach (Andrzej Rychard, for example, was interested in how system and anti-system could cohabit and endure without legitimacy or legitimation (Rychard \& Sulek 1988)) or to return to a sociology of values and representations to measure individuals' views and assessments of the situation. The latter approach confirmed the "sociological void" that had already been identified in the mid-1950s by Stefan Nowak's survey - the void, that is, between two extremes of identification: the Family and the Nation (Nowak 1966) - while still other sociologists probed what enabled a political system that seemed devoid of legitimacy to endure. For Mirosława Marody (1988), "collective good sense" - a variant of the "Kadarian compromise" concept - functioned as a kind of substitute for political legitimacy: individuals concocted survival niches for themselves within a system they did not endorse.

These two opposed approaches did produce different ways of conceptualising social reality. The claim among sociologists interested in mechanisms was that because the political power was by nature totalitarian, it dichotomised the structure: on one side, the Party and its elites; on the other, a more or less undifferentiated population. For sociologists of this persuasion, the structure of socialist societies was completely different from that of democratic, market societies. Sociologists interested in symptoms, meanwhile, went no further than researching stratification, and they claimed that socialist society was a variant of industrial society and was therefore composed of the same classes or strata.

The truly innovative approaches were those that, following the Hungarian economists, stressed the distribution and redistribution mechanisms peculiar to Soviet-type systems. Szelényi, Hankiss (1986), and Tamás Kolosi showed that Soviet-type societies were dual: two types of society cohabited, "governed" by different distribution systems - state redistribution mechanisms and market mechanisms. Hankiss went so far as to posit a parallel society, an echo of the concept of parallel economy.

We can see the usefulness of this paradigm of dual society for explaining what Weberian sociology could not: how a system that had exhausted its legitimation resources could continue to exist. But we can also see its usefulness in explaining the atypical end of that system: how and why it could manage to dissolve peaceably. For the paradigm showed how, in Soviet-type systems, political position determined an individual's overall social status by means of a "corrective" effect that became stronger with the later "invisible" "spontaneous" pressure towards privatisation and so 
towards a kind of market. With this paradigm it became possible to grasp precisely what was transitory and shifting in the social situation of postcommunist countries - countries where the power of market-based distribution mechanisms was increasing at the expense of state redistribution mechanisms. If we wanted to use Pierre Bourdieu's, James Coleman's, or Robert Putnam's concepts about the convertibility and mobility of different types of capital, we could say that in Soviet-type systems social position was largely determined by political capital, together with cultural capital in the final phase. So the higher one's education and/or useful skill level, the greater one's chances of attaining a top position in the various hierarchies and enjoying the advantages that came with it. In 1989, political capital, coalescing with social capital (networks), could finally culminate in economic capital, which then became determinant for the individual's social position in post-communist society. This argument dominated studies of the post-communist elites, as we shall see.

The underside of these debates on socialist society was a battle over methodology in which a number of Eastern European sociologists, including Stefan Nowak, were active. In response to what had been the absolute domination of historical materialism and dialectic, a debate developed on how the scope of sociological laws and discoveries were related to research costs. The economic argument concealed an ideological purpose: to disqualify those in favour of applying Marxism in sociology. To summarise the argument briefly, on one side was the objective of formulating great universal laws such as "The proletariat alone can put an end to social injustice because of its position in the capitalist socio-economic system," on the other, the gradation of hypotheses into micro, meso, and macro, with the understanding that only micro hypotheses were worthy of sociological investigation because they were based on a limited number of variables and indices and therefore empirically verifiable at a feasible financial cost. (This was universalism versus naturalism.) Gradually, the small group of methodology specialists and logicians who had introduced positivism and the quantitative approach (strongly influenced by Paul Lazarsfeld's methodology) grew to include the young sociologists who were once again being trained in faculties of sociology and philosophy at the University of Warsaw, University of Lódź, and Jagiellonian University in Kraków. By the 1970s and 1980s, and with varying degrees of intensity depending on the researcher, quantitativism and positivism had become the dominant approach, and the supremacy of English-language and especially American sociology was no longer contested. Analogous phenomena have been 
noted in "free society" sociology, particularly in France, where all dominant theoretical approaches gave priority to big systems: Durkheimism, like Marxism, dictated the law in university departments until the 1950s and even 1960s. The two worlds were of course still differentiated by the vital factors of oppression, state control, and political and professional risktaking that had serious existential consequences. And those differences varied with the degree of intolerance in each Sovietised country. The situation of Hungarian sociologists was completely different from that of East German sociologists, and the situation of Czechoslovakian or Russian sociologists differed radically from that of Polish sociologists.

But Eastern European sociologists were not cut off from the world or from major developments in international sociology, especially from the mid-1950s and 1960s. The Poles, Bulgarians (Congress of Varna), Hungarians, and Soviets took an active part, namely by way of the International Sociology Association. ${ }^{4}$ What separated them was their more or less subjective assessment - based, of course, on their observations of communist censor behaviour in their respective countries - of what was empirically acceptable to the authoritarian powers and what could be taken up and adapted to the circumstances of the Soviet-type political regime that these sociologists were an organic part of and with which they entertained complex relations, as explained above. Despite their contact with international and especially American sociology, Eastern European sociologists developed their own vision of what sociology is and should be. The result was that when their situation of political dependence finally ended they found themselves face-to-face with their discipline in its "raw state," the ways it had evolved outside "their world," and with a world that presented new enigmas.

\section{/// Conclusion}

It is worthwhile describing the context of early post-communism: specifically the resources available for the first sociological research (early 1980s)

\footnotetext{
${ }^{4}$ There are many indicators for assessing and ranking in international competition in connection with a particular academic discipline: number of indexed references, vitality of the related professional association, quantity of production in the home language and translations, and presence in international networks of excellence. Here it is worth noting that during the period under study, several presidents and vice-presidents of the International Sociological Association - the association most representative of the sociology research being done throughout the world - were Polish: Jan Szczepański (1966-1970) and Piotr Sztompka (president, 2002-2006), not to mention Stanisław Ossowski (vice-president, 1959-1962) and Magdalena Sokołowska (1978-1982). Szczepański, Ossowski and Sokołowska, then, held office during the communist regime.
} 
on communism and post-communism, the uncertain beginnings of this research, how it was perceived, and its blockage points.

Overall, Eastern European sociologists ended up developing convictions similar to their Western counterparts, though they were at times more dogmatic due to their prior political situations. The rejection of nonpositivist approaches; the belief that sociology was its own, independent discipline, which must remain free of influence from "parasite" disciplines; faith in an all-encompassing theoretical synthesis or the quest for a paradigm which, if not unique, would at least be dominant - not to mention the near-monopoly of American sociological thinking - were features shared by "free society" and "obedient" sociology. The only real difference was the emphasis. For example, in Western academic institutions, post-Marxist, anti-positivist sociology could cohabit with rising positivism, whereas Marxism and critical Marxist approaches were no longer really acceptable in the East, except in circles close to the state power. There was, however, one substantial difference: at the end of communism, Eastern European sociologists not only had to deal with the worldwide "crisis in sociology" but also to free themselves from the "habit" of operating under political constraint and to assimilate other constraints, this time originating in the liberal economy. The major changes in international sociology that had lastingly destabilised sociology under communism also upset post-communist arrangements for sociology. It could almost be said that in the encounter between Eastern and Western sociology, each seemed attracted to the other's role. Whereas "obedient" sociology wagered nearly everything on the positivist, "scientistic" approach and therefore on quantitativism which was paradoxically easy to practise under communism due to the abundant "funny money" proffered by the Marxist state (despite the fact that the research in question attacked its ideology) - in the democratic countries, qualitative approaches, largely influenced by philosophy (particularly phenomenology) and psychology, not to mention psychoanalysis, were gaining ground again. The normative boundary between "quality" (i.e., quantitative) sociology and "poor" (qualitative) sociology disappeared in the West well before communism collapsed in Europe. And it was not easy for Eastern Europeans to admit that their discipline was unlikely to become an exact science similar to natural science when this was the very argument they had used to combat Marxism, which they viewed as "nonscience." Yet another dimension of traditional sociological understanding

5 The split referred to here is not the one between facts and values, between "spontaneous"
sociologists ("experts") and objective sociologists (who distanced themselves from their research 
raised problems for the entire group, not to say generation, of Eastern European sociologists who began practising in the 1950s and 1960s. I'm referring to the axiom of the superiority of modern, modernising civilisation - precisely the type of civilisation that had been fairly thoroughly attained in Europe, the United States, and Japan and toward which the rest of the world seemed to be moving or to wish to move. For Eastern European sociologists - and Raymond Aron - developments in the West and East were two different facets of one and the same process. This assumption remains strong even now, when in fact many of the new social phenomena that gave signs of emerging in the twentieth century do not at all fit into an analysis in terms of modernisation.

The profusion of sociological and para-sociological schools in Europe eclipsed American sociology as little else could. "Despite globalisation, there was no reason to suspect that national intellectual traditions would converge" (Szacki 2003: 859). "American sociology not only ceased to be attractive to other countries - it had become so between the two world wars and immediately after the second one - but also began to undergo influences from European sociology, which recovered the position it had lost during the first half of the twentieth century" (ibid.). For sociologists who had been applying approaches shaped by the domination of communism, it was surprising and intensely bewildering to discover this surrounding reality.

Last, the pre-eminence of the empirical, which helped free sociology from the grip of philosophy (itself considered a pre-science), simultaneously instated sociology as an objective science and receded to such a degree that it became possible to reopen areas of sociology that had been heavily influenced by philosophy. Here, as in the case of the other trends mentioned, the ideological gap between Eastern European and Western European sociologists - the former more zealous positivists than their counterparts from democratic countries - made the Easterners extremely wary of the way social theory was evolving (Jonathan Turner described it as being like a philosophical discussion group). Moreover, according to Jerzy Szacki, the question of what properly belongs to sociology and what does not was no longer relevant. Eastern European sociologists, seasoned

object) hypothesised by Bourdieu, Chamboredon, and Passeron in Le Métier de Sociologue (1967), though it does resemble it. Bourdieu et al.'s epistemological doctrine is strongly criticised today by sociologists who see their discipline as the dual practice of observing facts and making them intelligible (restoring them) to the studied society in the form of expertise. On this question see Singly 2002. 
fighters in a battle for the purity of their discipline, could only have been shocked and offended at first by what looked like scientific eclecticism.

Bibliography:

/// Aron R. 1963. “Introduction,” [in:] M. Weber, Le Savant et le Politique, Union Générale d'Éditions, pp. 3-16.

/// Batygin G.S., Deviatko I.F. 1995. "Metamorfozy socjologii rosyjskiej" [Metamorphoses of Russian Sociology], [in:] Socjologia Europy ŚrodkowoWschodniej, 1956-1990 [Sociology of Central-Eastern Europe, 1956-1990], transl. L. Stetkiewicz, J. Mucha, eds. J. Mucha, M.F. Keen, Instytut Filozofii i Socjologii PAN, pp. 26-37.

/// Bauman Z. 1964. Zarys marksistowskiej teorii spokeczeństwa [Outline of a Marxist Theory of Society], Państwowe Wydawnictwo Naukowe.

/// Becskehazi A., Kuczi T. 1995. "Socjologia reformistycznego socjalizmu" [Sociology of the Reformist Socialism], [in:] Socjologia Europy SrodkowoWschodniej, 1956-1990 [Sociology of Central-Eastern Europe, 1956-1990], transl. L. Stetkiewicz, J. Mucha, eds. J. Mucha, M.F. Keen, Instytut Filozofii i Socjologii PAN, pp. 69-85.

/// Bourdieu P., Chamboredon J-C., Passeron J-C. 1967. Le Métier de Sociologue, Mouton.

/// Hankiss E. 1986. The Black Box: Interaction and Conflict of Social Paradigms in Contemporary Societies (the Case of Hungary), Center for Value Sociology.

/// Hochfeld J. 1963. Studia o marksistowskiej teorii spoleczeństwa [Studies in Marxian Theory of Society], Państwowe Wydawnictwo Naukowe.

/// Hungarian Statistical Office. 1967. Social Stratification in Hungary (A Survey of 15,000 Housebolds Conducted in 1963), KSH.

/// Karpiński J. 1985. Polska, komunizm, opozycja [Poland, Communism, and the Opposition], Polonia.

/// Konrád G., Szelényi I. 1979. La marche au pouvoir des intellectuels, Editions du Seuil [published in English in the same year as The Intellectuals on the Road to Class Power, Harcourt Brace Jovanovich]. 
/// Kuroń J., Modzelewski K. 1967. Lettre ouverte au Parti Owvrier Unifié Polonais, Cahiers Rouges.

/// Malanowski J. 1981. Polscy robotnicy [Polish Workers], Książka i Wiedza.

/// Malewski A. 1964. O rastosowaniach teorii zachowania [On Applications of Behaviour Theory], Państwowe Wydawnictwo Naukowe.

/// Marody M. 1988. "Sens zbiorowy a stabilność i zmiana ładu społecznego," [in:] Legitymacja. Klasyczne teorie i polskie doświadcrenia [Legitimacy: Classical Theories and Polish Experiences], eds. A. Rychard, A. Sułek, Polskie Towarzystwo Socjologiczne, pp. 269-301.

/// Mink G. 1975. "Concept et sondages d'opinion publique en Union sovétique," Revue d'études comparatives Est-Ouest, vol. 6(1), pp. 207-218.

/// Mink G. 1981. "Sondages, sondeurs, opinion publique et pouvoir politique en Pologne à la fin des années soixante-dix," Revue d'Etudes Comparatives Est-Ouest, vol. 12(1), pp. 143-160.

/// Mink G. 1987a. "Un Sociologue Hongrois parle (Interview de Elemér Hankiss par Georges Mink)," L'Autre Europe, vol. 13, L'Age d'Homme, pp. 29-36.

/// Mink G. 1987b. "Une autre sociologie? Essai sur les rapports entre les sociologues, le pouvoir, la communauté scientifique et la société dans les systèmes de type soviétique," L'Autre Europe, vol. 13, L'Age d'Homme, pp. $6-22$.

/// Mink G. 1988. "Réhabilitation des sondages d'opinion en URSS, Pologne et Hongrie," Le Courrier des Pays de l'Est, vol. 329, pp. 18-28.

/// Nowak S. 1966. "Psychologiczne aspekty przemian struktury społecznej i ruchliwości społecznej” [Psychological Aspects of Changes in Social Structure and Social Mobility], Studia Socjologiczne, vol. 21(2), pp. 75-105.

/// Rychard A., Sułek A., eds. 1988. Legitymacja. Klasyczne teorie i polskie doswiadczenia [Legitimacy: Classical Theories and Polish Experiences], Polskie Towarzystwo Socjologiczne.

/// de Singly F. 2002. "La sociologie, forme particulière de conscience," [in:] A quoi sert la sociologie?, ed. B. Lahire, La Découverte, pp. 13-42. 
/// Szacki J. 2003. Historia myśli socjologicznej [History of Sociological Thought], Wydawnictwo Naukowe PWN.

/// Szelényi I. 1986-1987. "The Prospects and Limits of the East European New Class Project: An Auto-Critical Reflection on The Intellectuals on the Road to Class Power," Politics and Society, vol. 15(2), pp. 103-144.

/// Tymowski A. 1977. "Struktury społeczne: nowe aspekty badań" [Social Structures: New Aspects of Research], Odra, vol. 6, pp. 19-27.

/// Wasilewski J. 1978. "Społeczne mechanizmy selekcji na wyższe stanowiska kierownicze" [Mechanisms of Selection for Management Positions], Studia Socjologiczne, vol. 2, pp. 181-207.

/// Wesołowski W. 1962. Studia z socjologii klas i warstw społecznych [Studies in the Sociology of Class and Social Strata], Książka i Wiedza.

/// Wesołowski W., Słomczyński K.M. 1977. Investigations on Class Structure and Social Stratification in Poland, 1945-1975, The Polish Academy of Sciences, Institute of Philosophy and Sociology.

\section{/// Abstract}

The model of society put forward by Marxist theoreticians as descriptive of a post-revolutionary society had a quasi-constitutional status in countries that claimed to adhere to Soviet-type socialism, particularly those of Eastern Europe. As the model's main function was to legitimise the actions of those who wielded power, it acquired doctrinal significance. In the Eastern European countries, the history of the sociology of social structure and stratification clearly illustrates the conservative nature of official doctrine. However, the real mechanisms of society, in so far as they deviated from the official paradigm, upset doctrinal stability and may consequently have led, if not to a revision of the official dogmas, then to the acceptance of a certain degree of flexibility. In order to understand the development of the theoretical analysis of social stratification and social inequalities (the most sensitive area of debate) in totalitarian and post-totalitarian Soviettype societies, it must be noted that post-war sociology has reflected a continuing effort by sociologists to create an independent scientific framework for their discipline. This is why we try, in this article, to combine evaluating the attitudes of different Eastern European sociologists from across the 
political spectrum with the evolution and adaptation of their theoretical approaches and creativity.

Keywords:

sociology of social structure, sociologists and the sociology profession, Soviet-type regimes (totalitarian and post-totalitarian), social diagnosis competition in Soviet-type regimes

/// Georges Mink - emeritus director of research at the Institut des Sciences Sociales du Politique, Université de Paris X, visiting professor at Science Po, Paris, and permanent professor at the College of Europe, Natolin. He has led research teams at the Observatoire Sociologique de l'URSS et de l'Europe de l'Est (OSEUS-CNRS), and the Centre des recherches sur les sociétés postcommunistes (CRESPO-CNRS). Between 2001 and 2003, he was director of the Centre Français de Recherches en Sciences Sociales in Prague (MAE-CNRS). He was director of the Revue d'Études comparatives Est-Ouest (1999-2004), one of founders of the journal Géopolitique, and member of the board of several other international journals. In 2015 he was elected president of the ICCEES. He has been member of several professional executive bodies, including the administration councils of Radio France Internationale (1989-1994) and the Société Historique et Littéraire Polonaise de Paris, and the scientific council of the Social Sciences Faculty of Charles University. His recent books are History, Memory and Politics in Central and Eastern Europe: Memory Games (co-edited) and La Pologne au coeur de l'Europe, 1914 à nos jours, Histoire politique et conflits de mémoire (2015), Polish updated translation Polska w sercu Europy. Od roku 1914 do czasów najnows zych: historia polityczna i konflikty pamieci (2017).

Email: georges.mink@coleurope.eu 
